\title{
A Baltic Ice Lake lowstand of latest Allerød age in the Arkona Basin, southern Baltic Sea
}

\author{
Ole Bennike and Jørn Bo Jensen
}

After the last deglaciation, the Baltic Sea underwent a complex salinity history and dynamic shore-level development with several lacustrine and marine stages: the Baltic Ice Lake, the Yoldia Sea, the Ancylus Lake and the Littorina Sea (Björck 1995). In connection with shallow seismic profiling in the south-western Baltic Sea, two marked and widespread erosional unconformities have been identified (Jensen $e t$ al. 1997, 1999; Lemke et al. 1998; Larsen 2004). The older unconformity occurs within sediments deposited in the Baltic Ice Lake, whereas the younger one separates Baltic Ice Lake sediments from Holocene lake and mire deposits. The latter unconformity is dated to the transition between the Younger Dryas and the Holocene, corresponding to $c .11 .7 \mathrm{cal}$. ka BP and formed due to a sudden drop in the level of the icedammed Baltic Ice Lake of around $25 \mathrm{~m}$, caused by ice recession from Mt. Billingen in south central Sweden.

The age of the older erosional unconformity is poorly constrained. However, it has been suggested that the level of the Baltic Ice Lake also experienced a sudden drop during the Allerød chronozone. The temperature increased during the Allerød, and it is possible that the margin of the Fennoscandian Ice Sheet also receded from the Mt. Billingen area at this time. If so, the older erosional unconformity may have formed in connection with an early drainage of the Baltic Ice Lake.

The question about such an early lake-level fall was discussed by Björck (1995), who listed a number of arguments for and against it. One of the arguments for drainage is that evidence of a rapid lake-level fall is seen in both south-eastern Sweden and in other Baltic countries. A study in southwestern Sweden indicates a high discharge of freshwater, and data from south central Sweden indicate a significant glacial recession west of Mt. Billingen during the Allerød, which could have led to drainage of the Baltic Ice Lake. It has been suggested that drainage happened around $13 \mathrm{cal}$. ka ago (Uścinowicz 2006; Andrén et al. 2011).

In connection with sediment coring in the Arkona Basin, firm evidence of an early lowstand was for the first time identified in a sediment core. An organic-rich sediment which can be referred to this lowstand was found, and material was submitted for ${ }^{14} \mathrm{C}$ dating. The aim of this paper is to report on the age and its implications. The location of the coring site in the Arkona Basin is shown in Fig. 1. The basin is up to
$49 \mathrm{~m}$ deep and the surface of the till is found at a depth of 30 to $70 \mathrm{~m}$ (Moros et al. 2002).

\section{Material and methods}

Sediment coring was carried out using a $10 \mathrm{~cm}$ diameter vibrocorer with a $6 \mathrm{~m}$ long steel tube. Normally, coring positions are selected from high-resolution, shallow seismic profiles, but in the deeper parts of the Arkona Basin, gas-bearing, organic-rich, Holocene marine sediments are widespread and hamper the use of seismic data. Hence the core described here was collected at a site with poor seismic data. The core was sampled at a water depth of $39.5 \mathrm{~m}$, at $54^{\circ} 45.005^{\prime} \mathrm{N}, 13^{\circ} 45.876^{\prime} \mathrm{E}$. The core was collected $c .5 \mathrm{~km}$ ENE of the northern end of a seismic profile published by Lemke et al. (1998), where the unconformity is clearly seen. The lower unconformity is also seen on seismic data collected in the region during the Baltic Pipe survey (Larsen 2004). We collected two cores at the site, designated 258000-1 and 258000-2. The first core was collected in plastic foil, split lengthwise in the ship laboratory and described and subsampled for palaeoecological analysis. The second core was collected in a PVC tube and cut into $1 \mathrm{~m}$ sections for storage. However, the second core penetrated somewhat deeper than the first core, and in the core catcher, clay was found with abundant plant remains underlain by clay-rich, mediumgrained sand. Ten $1 \mathrm{~kg}$ samples from core 258000-1 and from

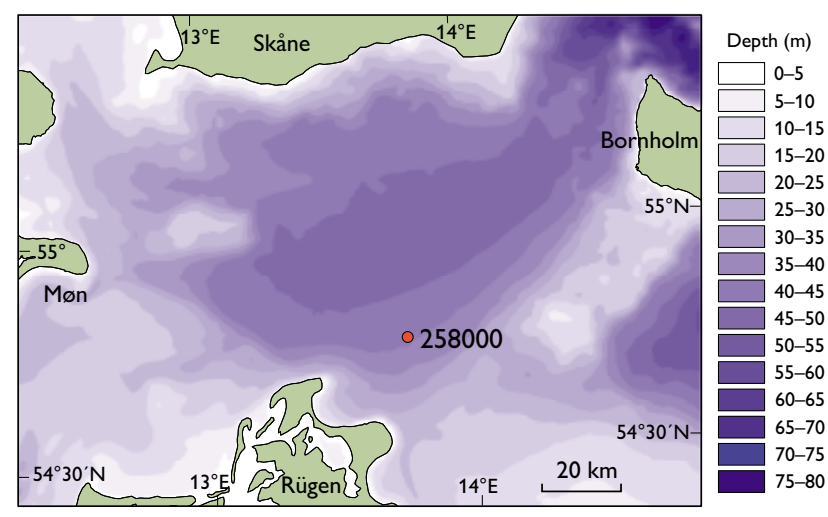

Fig. 1. Bathymetrical map of the Arkona Basin. The red dot shows the location of the studied sediment core. The core site is also shown on Fig. 5. 


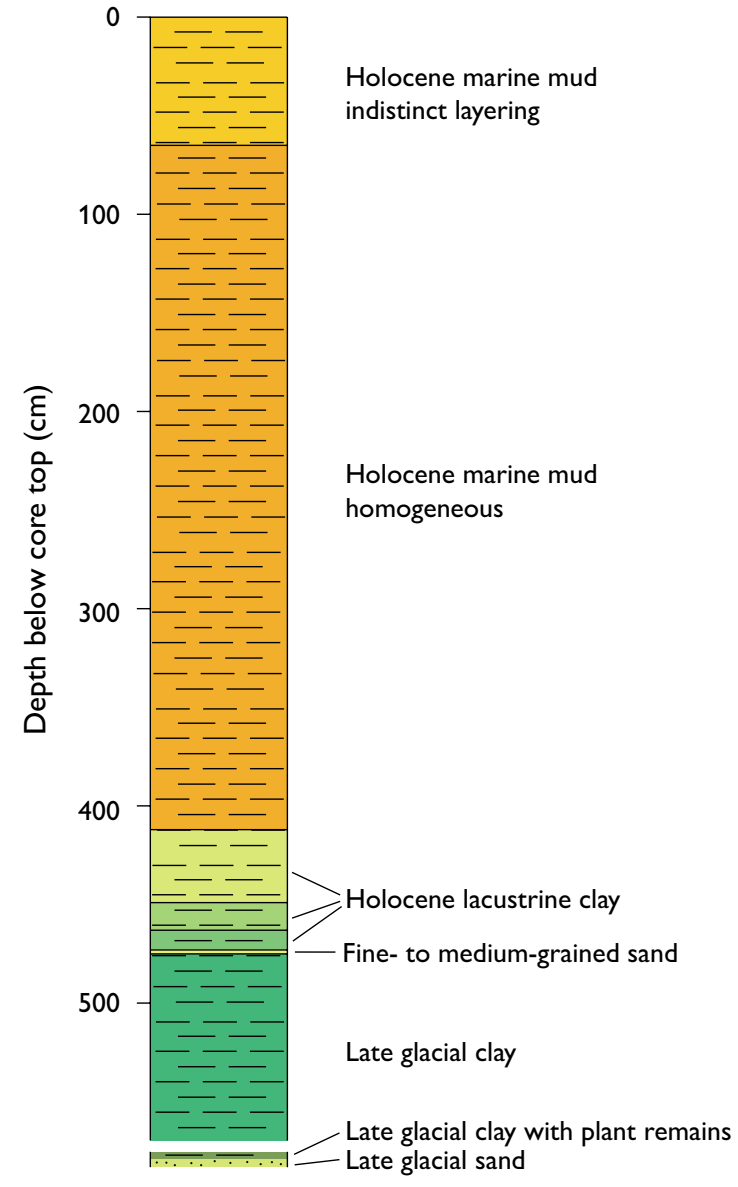

Fig. 2. Composite lithological log of core 258000 from the Arkona Basin. The two lower units were only found in core $258000-2$. The core numbers refer to the system used at the Department of Marine Geology at the Institute for Baltic Sea Research in Warnemünde. the core catcher of 258000-2 were brought to the Geological Survey of Denmark and Greenland, where the samples were wet sieved shortly after the cruise. Fruits of Cladium mariscus (a reed plant) were dried and shortly after submitted for accelerator mass spectrometry (AMS) radiocarbon age determination at the Leibniz Laboratory for Radiometric Dating and Isotope Research in Kiel, Germany.

\section{Results and discussion}

Core 258000-1 consists of olive-grey mud from the core top down to a depth of $412 \mathrm{~cm}$ (Fig. 2). Some shells of Macoma balthica and Mytilus edulis were noted, which shows that the mud is marine and of Holocene age. From 412 to $473 \mathrm{~cm}$, clay without carbonate is found; this succession was divided into three units according to variations in colour and texture. Shells and head shields of Chydoridae (cladocerans, water fleas) are common, head capsules of larvae of Chironomidae (non-biting midges) are present but rare, egg cocoons of the fish leach Piscicola geometra were found in two samples, and statoblasts of the bryozoan Cristatella mucedo in four samples (Fig. 3; Table 1). These invertebrate remains show that the clay was deposited in a lake. The presence of rare remains of Betula sect. Albae (tree birch) and Pinus sylvetris (pine) indicates an early Holocene age. The lower part was rich in radicells (tiny roots) of reed plants, which show that the shoreline was not far away from the coring site. The clay was probably deposited in the Ancylus Lake and perhaps in the Yoldia Sea.

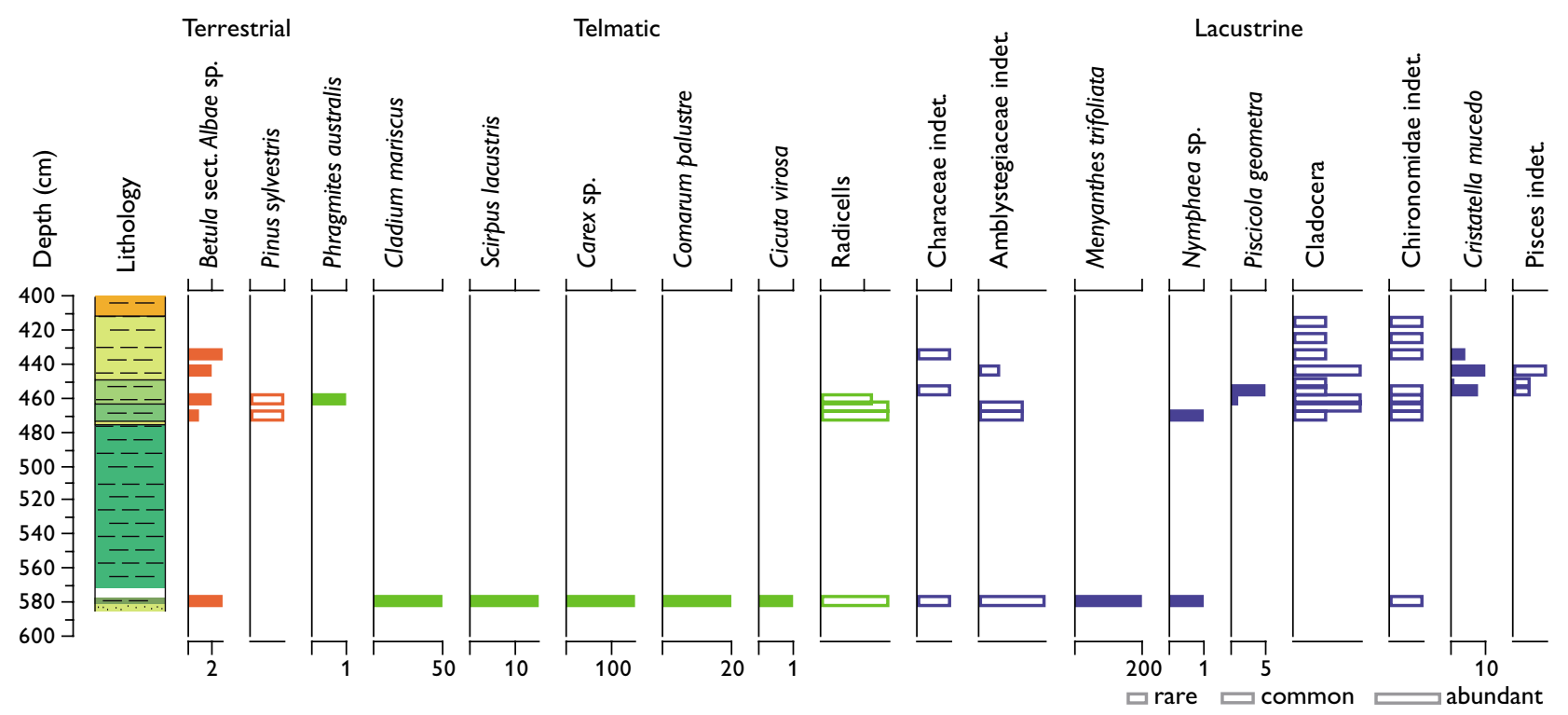

Fig. 3. Macrofossil diagram of the lower parts of cores 258000-1 and 258000-2 from the Arkona Basin. The hollow bars show remains not counted. 
Table 1. Macrofossils in core 258000

\begin{tabular}{|c|c|c|c|c|c|c|c|c|c|c|c|c|c|c|}
\hline 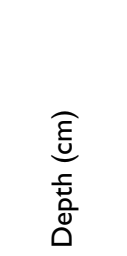 & 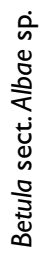 & 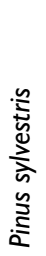 & 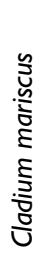 & 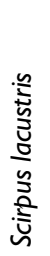 & 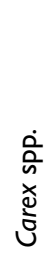 & 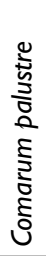 & 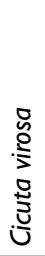 & 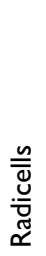 & 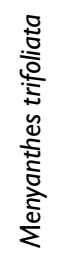 & 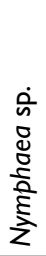 & 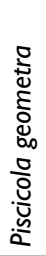 & 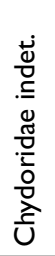 & 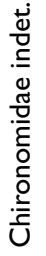 & 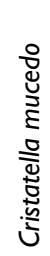 \\
\hline $12-420$ & - & - & - & - & - & - & - & - & - & - & - & C & $r$ & - \\
\hline $420-430$ & - & - & - & - & - & - & - & - & - & - & - & c & $r$ & - \\
\hline $430-440$ & 3 & - & - & - & - & - & - & - & - & - & - & C & $r$ & 4 \\
\hline $440-449$ & 2 & - & - & - & - & - & - & - & - & - & - & C & - & 10 \\
\hline $449-454$ & - & - & - & - & - & - & - & - & - & - & - & c & - & 1 \\
\hline $454-459$ & - & - & - & - & - & - & - & - & - & - & 5 & c & $r$ & 8 \\
\hline $459-463$ & 2 & $r$ & - & - & - & - & - & C & - & - & 1 & c & $r$ & - \\
\hline $463-468$ & - & - & - & - & - & - & - & C & - & - & - & c & $r$ & - \\
\hline $468-473$ & 1 & $r$ & - & - & - & - & - & C & - & 1 & - & C & $r$ & - \\
\hline c. 580 & 3 & - & 50 & 15 & 150 & 20 & 1 & c & 200 & 1 & - & $r$ & $r$ & - \\
\hline
\end{tabular}

r: rare, c: common.

The clay is underlain by $2 \mathrm{~cm}$ of fine- to medium-grained grey sand. This thin sand layer may have been deposited at or after the final drainage of the Baltic Ice Lake. Below the sand layer and down to the bottom of the core at $570 \mathrm{~cm}$, grey clay is found. This unit is rich in carbonate and barren of fossils and it is interpreted as late-glacial clay deposited in the Baltic Ice Lake during the Younger Dryas.

From the deeper core 258000-2, a sample rich in plant remains was analysed for macrofossils. The plant remains were dominated by fruits and seeds of the telmatic plants $M e$ nyanthes trifoliata and fruits of Carex, mainly Carex vesicaria, Cladium mariscus, Scirpus lacustris, Comarum palustris and Cicuta virosa (Fig. 3). Limnic plants and animals were represented by a seed of Nymphaea sp., common stems of Amblystegiaceae (mosses, not shown), rare shells and head shields of Chydoridae and rare head capsules of larvae of Chironomidae. The fossil assemblage and in particular the occurrence of abundant remains of telmatic plants show that the sediment was deposited in shallow water near the shore of a lake, probably just outside the reed belt. The presence of fruits of Betula sect. Albae indicates that the land was covered by birch forests.

The sample of Cladium mariscus fruits yielded an age of $10980 \pm 55{ }^{14} \mathrm{C}$ years BP (KIA-21680). This is calibrated to $12.674-13.069 \mathrm{cal}$. ka BP, according to the INTCAL09 dataset, which corresponds to the youngest part of the Allerød chronozone or the oldest part of the Younger Dryas. An age corresponding to the warm Allerød Chronozone was expected from the fossil assemblage, because Cladium mariscus and Scirpus lacustris are thermophilous plants. Cladium mariscus was recorded from late-glacial deposits in south-eastern Denmark by Bennike \& Jensen (1995), but its presence was probably due to down-core contamination, and there are no secure records of it from late-glacial deposits in

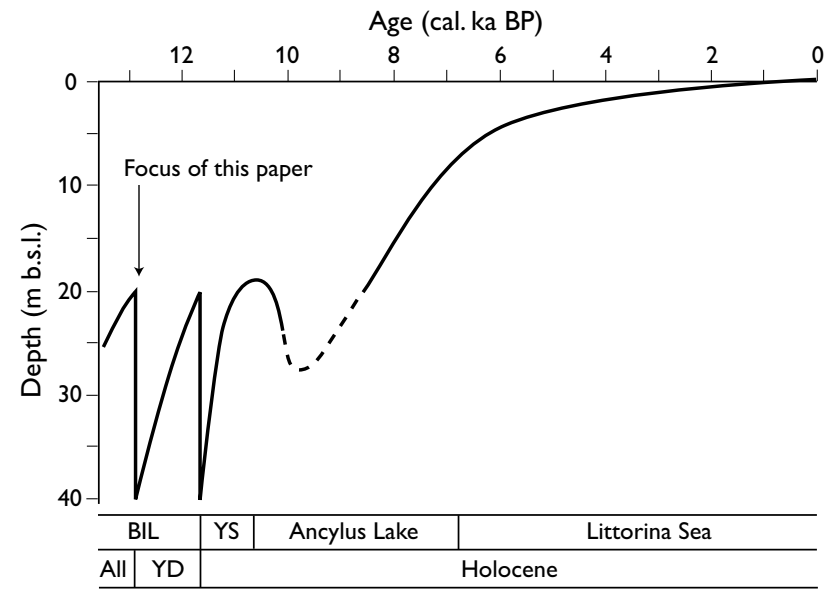

Fig. 4. Tentative curve showing relative shore-level changes in the Arkona Basin during the late-glacial and the Holocene. ka: kilo-annum (1000 years), BIL: Baltic Ice Lake, YS: Yoldia Sea, All: Allerød, YD: Younger Dryas. Modified from Bennike \& Jensen (1998).

Denmark (Iversen 1954; Jensen et al. 1997; Bennike et al. 2004). Its northern geographical limit during the Allerød may thus have been located near the coring site.

As the core was collected at a water depth of $39.5 \mathrm{~m}$ and the sample comes from a core depth of $c .5 .8 \mathrm{~m}$, the dated sample comes from a depth of $c .45 .3 \mathrm{~m}$ below present sea level. The sediment is fine-grained and was probably deposited at a water depth of several metres, and we suggest that the shore level during deposition was around $40 \mathrm{~m}$ lower than at present. Both before and after this lowstand episode, the relative shore level was around $20 \mathrm{~m}$ below the present sea level according to Jensen et al. (1997). This implies that the shore-level fall towards the end of the Allerød chronozone was of the same magnitude as the fall at the Younger Dryas Holocene transition, i.e. considerably more than $5-10 \mathrm{~m}$ as suggested by Björck (1995). The new data allow us to modify the shore-level model proposed by Bennike \& Jensen (1998) and extend it back in time. Figure 4 shows a new model for relative shore-level changes in the Arkona Basin from the last deglaciation to the present. It is seen that transgressions were interrupted by sudden regressions.

South of the Arkona Basin, late-glacial sediments reach elevations lower than $20 \mathrm{~m}$ (Lampe 2005). However, the relationship between these sediments and the regional shore level of the southern Baltic Basin is uncertain. Some of the sediments are glaciofluvial and were deposited above shore level, other late-glacial sediments may have been deposited in local basins, perhaps in part dammed by bodies of stagnant ice.

At present, the most enigmatic stage in the history of the Baltic Basin is that of the early Holocene Ancylus Lake; the shore-level curve for this stage has been drawn as a dashed line on Fig. 4. It has been suggested that the Ancylus regres- 


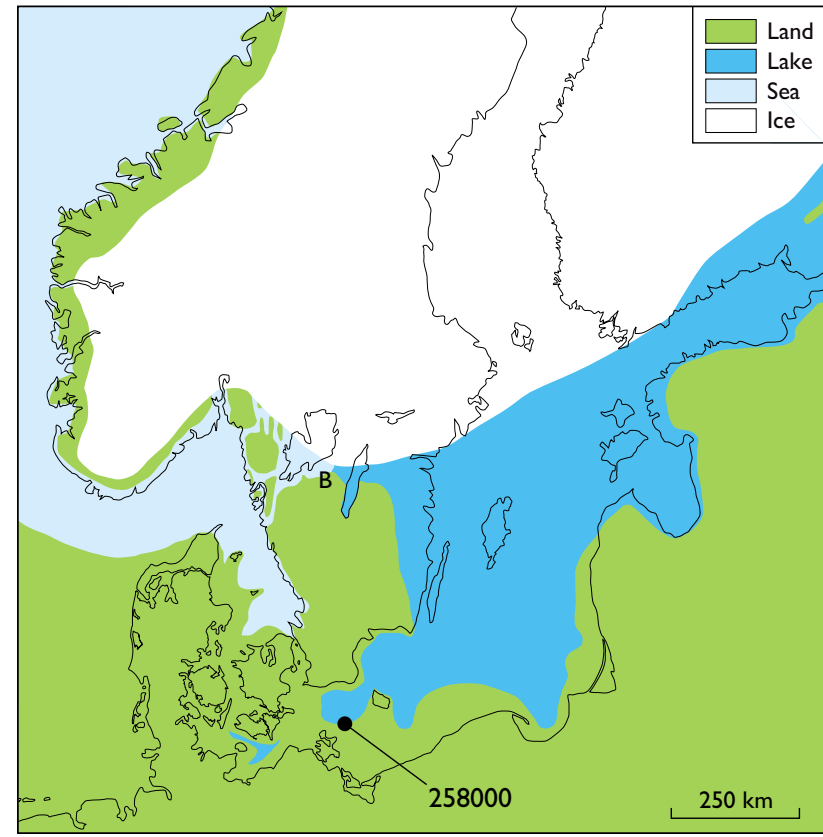

Fig. 5. Generalised palaeogeographical map of the Baltic region after the drainage at the end of the Allerød. Modified from Björck (1995) and Wohlfahrt et al. (2008). B: Billingen.

sion was around $20 \mathrm{~m}$ (Björck 1995), but more recently figures of $5 \mathrm{~m}$ and $10 \mathrm{~m}$ were also proposed (Björck et al. 2008; Rosentau et al. 2013). No erosional unconformity has been reported from the south-western Baltic Basin that formed during this regression (Jensen et al. 1999).

Figure 5 shows a model of the palaeogeography of the Baltic Basin after the late Allerød drainage. Although the Baltic Basin was now at the same level as the sea, it probably remained a freshwater lake. The connection to the sea was narrow, and we suggest that the outflow of huge amounts of fresh water coming from rivers and from the melting ice sheet hindered seawater from entering the Baltic Basin.

\section{Concluding remarks}

The rich occurrence of remains of reed plants at a depth of $45 \mathrm{~m}$ below sea level in the Arkona Basin provides firm evidence of a lowstand. A radiocarbon age shows that it occurred at the end of the Allerød Chronozone. We suggest that the shore level fell about $20 \mathrm{~m}$, similar to the shore-level fall at the Younger Dryas - Holocene boundary.

\section{Acknowledgements}

The captain and crew of the former R/V Alexander von Humboldt from the Institute for Baltic Sea Research in Warnemünde are thanked for their help during the marine cruise. This paper is dedicated to the memory of Wolfram Lemke, who invited us to take part in the cruise during which cores $258000-1$ and 258000-2 were collected.

\section{References}

Andrén, T., Björck, S., Andrén, E., Conley, D., Zillén, L. \& Anjar, J. 2011: The development of the Baltic Sea during the last 130 ka. In: Harff, J. et al. (eds): The Baltic Sea Basin, 75-97. Berlin: Springer Verlag.

Bennike, O. \& Jensen, J.B. 1995: Near shore Baltic Ice Lake deposits in Fakse Bugt, southeast Denmark. Boreas 24, 185-195.

Bennike, O. \& Jensen, J.B. 1998: Late- and postglacial shore level changes in the southwestern Baltic Sea. Bulletin of the Geological Society of Denmark 45, 27-38.

Bennike, O., Jensen, J.B., Lemke, W., Kuijpers, A. \& Lomholt, S. 2004: Late- and postglacial history of the Great Belt, Denmark. Boreas 33, 18-33.

Björck, S. 1995: A review of the history of the Baltic Sea, 13.0-8.0 ka BP. Quaternary International 27, 19-40.

Björck, S., Andrén, T. \& Jensen, J.B. 2008: An attempt to resolve the partly conflicting data and ideas on the Ancylus-Littorina transition. Polish Geological Institute Special Papers 23, 21-26.

Iversen, J. 1954: The Late-Glacial flora of Denmark and its relation to climate and soil. Danmarks Geologiske Undersøgelse II. Række 80, 87-119.

Jensen, J.B., Bennike, O., Witkowski, A., Lemke, W. \& Kuijpers, A. 1997: The Baltic Ice Lake in the southwestern Baltic: sequence-, chrono- and biostratigraphy. Boreas 26, 217-236.

Jensen, J.B., Bennike, O., Witkowski, A., Lemke, W. \& Kuijpers, A. 1999: Early Holocene history of the southwestern Baltic Sea: the Ancylus Lake stage. Boreas 29, 437-453.

Lampe, R. 2005: Lateglacial and Holocene water-level variations along the NE German Baltic Sea coast: review and new results. Quaternary International 133-134, 121-136.

Larsen, C.S. 2004: Sequence stratigraphy based on vibrocore description and shallow seismic data from the south-western Baltic Sea. Danmarks og Grønlands Geologiske Undersøgelse Rapport 2004/53, 28 pp.

Lemke, W., Endler, R., Tauber, F., Jensen, J.B. \& Bennike, O. 1998: Lateand postglacial sedimentation in the Tromper Wiek (western Baltic). Meyniana 50, 155-173.

Moros, M., Lemke, W., Kuijpers, A., Endler, R., Jensen, J.B., Bennike, O. \& Gingele, F. 2002: Regression and transgressions of the Baltic basin reflected by a new high-resolution deglacial and postglacial lithostratigraphy for Arkona Basin sediments (western Baltic Sea). Boreas 31, 151-162.

Rosentau, A. et al. 2013: Stone Age settlement and Holocene shore displacement in the Narva-Luga Klint Bay area, eastern Gulf of Finland. Boreas. bttp://dx.doi.org/10.1111/bor.12004

Uścinowicz, S. 2006: A relative sea-level curve for the Polish southern Baltic Sea. Quaternary International 145-146, 86-105.

Wohlfarth, B., Björck, S., Funder, S., Houmark-Nielsen, M., Ingólfsson, Ó., Lunkka, J.-P., Mangerud, J., Saarnisto, M. \& Vorren, T. 2008: Quaternary of Norden. Episodes 31, 73-81. 